\title{
Prospective assessment of complications associated with ultrasound activated resorbable pin osteosynthesis in pediatric craniofacial surgery: preliminary results
}

\author{
E. Nkenke; E. Vairaktaris; S. Schwarz*; I. Eyüpoglu**; O. Ganslandt**; T. Leis***; C. Knipfer and F. Stelzle
}

Departments of Oral and Maxillofacial Surgery. *Pathology. **Neurosurgery and ***Pediatrics. University Hospital Erlangen. Erlangen. Germany.

\section{Summary}

Ultrasound activated resorbable pin osteosynthesis (UARPO) has recently shown favourable results in operations on children suffering for craniosynostosis. However, data on complications coming with this new technique in children suffering from craniosynostoses are scarce and have only been assessed retrospectively so far. It has been the aim of the present study to prospectively follow up children undergoing craniosynostosis surgery with a focus on complications related to UARPO materials.

Ten pediatric patients (3 female/7 male) were operated due to craniosynostosis at an average age of 9.1 \pm 3.8 months using UARPO (SonicWeld/Resorb-X, KLS Martin, Tuttlingen, Germany). Clinical followup evaluations were carried out 1, 3, 6, 9, 12 and 18 months after surgery according to signs of local infection, stability of the remodeled cranial vault and the palpability of the osteosynthesis material. If secondary surgery was necessary, the indication was documented and evaluated by histological and wound smear examinations.

No intra-operative or postoperative complications during the inpatient period occurred. 3 patients needed secondary operation due to a localized chronic swelling at the former incision site which developed 3, 9 and 12 months after the operation. Histological examinations yielded a giant cell formation surrounding the resorbable materials in all cases. Additionally, the wound smear showed a bacterial infection in one site.

The current prospective study is the first in the field. It reveals a high percentage of delayed foreign body reactions with UARPO, bearing the need of secondary surgery. It seems that this high complication rate found in the present prospective study may weigh out the advantages of UARPO.

Recibido: 5-04-11. Aceptado: 6-08-11
KEY WORDS. Craniofacial surgery. Craniosynostosis. Resorbable materials. Ultrasound activated resorbable pin osteosynthesis.

Estudio prospectivo evaluando complicaciones de cirugía craneofacial pediátrica usando clavos reabsorbibles activados con ultrasonidos: resultados preliminares

Resumen

Recientemente, la osteosíntesis activada por ultrasonografía con clavos reabsorbibles (OAURC) ha demostrado resultados favorables con operaciones en niños que sufren de craneosinostosis. Sin embargo, los datos actuales sobre complicaciones provenientes con esta técnica nueva en niños que sufren de craneosinostosis son escasos, hasta ahora estos datos solamente han sido evaluados retrospectivamente. El propósito de este estudio, es el seguimiento prospectivo de aquellos niños sometidos a cirugía por craneosinostosis, enfocándose específicamente en complicaciones relacionadas con el uso de los materiales aplicando OAURC.

Diez pacientes pediátricos (3 femeninos/7 masculinos) fueron operados utilizando OAURC (SonicWeld/ Resorb-X, KLS Martin, Tuttlingen, Alemania) debido a craneosinostosis; la edad promedio de esos pacientes fue de $9.1 \pm 3.8$ meses. Se llevaron a cabo examinaciones clínicas de seguimiento $1,3,6,9,12$ y 18 meses después de la cirugía buscando señas de infección local, estabilidad de la bóveda craneoencefálica y palpando la zona con osteosíntesis. En caso de que se requiriera una segunda operación quirúrgica, la indicación para ella se documentaba y se evaluaba por medio de exámenes histológicos y con laminillas citológicas de la herida.

No hubo complicaciones intra - ni post operatorias durante el periodo de hospitalización. Tres pacientes necesitaron una segunda operación debido a una inflamación localizada en el área de la incisión quirúrgica, la cual se llevó a cabo 3, 9 y 12 meses después de la primera operación. En todos estos casos, los exámenes 
histológicos demostraron formación de granulomas con células gigantes rodeando el material reabsorbible. Además, en un caso, las laminillas citológicas obtenidas de la herida demostraron una infección por bacterias.

Este estudio prospectivo es el primero en el uso de este procedimiento. Revela un porcentaje alto de reacción inflamatoria granulomatosa por cuerpo extraño con OAURC, llevando a la necesidad de proceder con una segunda operación quirúrgica.

Sale que el alto porcentaje de complicaciones encontradas en este estudio prospectivo puede sobre pesar las ventajas que ofrece OAURC y que por lo tanto, el uso clínico de esta técnica, no sea recomendable hasta que haya más datos prospectivos utilizando una población con un número mayor de pacientes que demuestren un resultado más favorable.

PALABRAS CLAVE. Cirugía craneofacial. Craneosinostosis. Materiales reabsorbibles. Osteosíntesis activada por ultrasonido en clavos reabsorbibles

\section{Introduction}

Resorbable plates have advanced the technique of bony fixation in craniosynostosis surgery. Some well known problems of metal osteosynthesis materials like temperature-induced paresthetic pain or interference with imaging modalities can be avoided with resorbable plates and pins $^{7,28}$. Although it has not been proven scientifically so far, resorbable osteosynthesis should not hamper the growth process, which is most important in children suffering from craniosynostosis ${ }^{8}$. The most relevant advantage of resorbable osteosynthesis systems is that there is no second-stage operation necessary to remove the material ${ }^{24}$. A large series of 216 cases has shown that the complication rate with bioabsorbable osteofixation devices is minimal and accounts for less than 5 percent of the patients ${ }^{18}$.

However, some disadvantages with the use of resorbable plating systems should not be ignored ${ }^{3}$. For proper load bearing comparable to metal plates the dimensions of resorbable plates need a higher profile leading to visible or palpable hardware postoperatively until resorption of the material ${ }^{12}$. The inflammatory response seems to depend on the kind of resorbable materials used but is not described to be of major impact concerning the operation outcome ${ }^{10,12}$. However, low-grade foreign body reactions to resorbable materials used in cranio-facial surgery are described $d^{2,20}$. Resorbable screws require a drill hole that must be tapped. This procedure increases operative time. The placement of these screws is somewhat more surgeon- and technique-sensitive than with conventional metallic plating systems ${ }^{12}$. Resorbable screws require slower drilling rates into the bone. They are placed in a non-heated fashion at
90 degrees to the bone. If drilling occurs at a high speed or at an acute angle to the bone, friction heat is created. As a consequence, it becomes difficult to place screws in a reliable manner ${ }^{19}$. This problem has been overcome by inserting pins instead of screws with the aid of ultrasound. It has been shown previously that the operation time required for applying osteosynthesis materials was reduced by $50 \%{ }^{21}$. Since the pins are not exposed to tensional forces the material does not fracture ${ }^{21}$.

Like in every other field new advances in resorbable osteosynthesis have to prove their relevance over short and long term. In the past it has been shown that the rate of complications related to resorbable osteosynthesis material should not be underestimated. It accounts for 15.4\% of the patient cases. Reoperation seems to be necessary in $1.9 \%{ }^{25}$.

Data on complications caused by ultrasound activated resorbable pin osteosynthesis in children operated on because of craniosynostoses are scarce $e^{4,7,24}$. Ultrasound activated resorbable pin osteosynthesis is in use at the Erlangen University Hospital since 2006. Until the middle of 2008 a number of complications were encountered with this material. In order to get a more realistic view on the frequency of complications, it was decided to perform a prospective study. Therefore, it has been the aim of the present study to follow up children undergoing craniosynostosis surgery prospectively with a focus on complications related to ultrasound activated resorbable pin osteosynthesis.

\section{Materials and methods}

Between January 2008 and December 2009 ten pediatric patients with craniosynostosis were operated on by a team of experienced craniofacial surgeons with more than ten years experience in the field (Table 1). The prospective study was approved by the institutional ethical committee of the university of Erlangen-Nuremberg according to the World Medical Association Declaration of Helsinki (June 1964). Informed consent was given for the cranial vault remodeling by the parents of each patient. Three female and seven male patients were included in the study. Two patients suffered from hypophosphatasia. Cranial vault reconstructions were carried out in seven cases of scaphocephaly, in one case of oxycephaly and in two cases of trigonocephaly. The average age of the patients at the time of surgery was $9.1 \pm 3.8$ months.

Surgery was carried out in an interdisciplinary approach by a neurosurgeon and an oral and maxillofacial surgeon. All patients received perioperative antibiotic prophylaxis. After coronal incision and subperiosteal dissection craniotomy was performed. Resorbable osteosynthesis 4hole plates, consisting of poly D,L-lactide acid (PDLLA) (Resorb-X, KLS Martin, Tuttlingen, Germany) with a thic- 
Table 1

Basic patient data

\begin{tabular}{|c|l|l|l|l|l|r|}
\hline $\begin{array}{c}\text { Patient } \\
\text { no. }\end{array}$ & Diagnosis & Sex & $\begin{array}{c}\text { Age at } \\
\text { the time of } \\
\text { cranioplasty } \\
\text { (months) }\end{array}$ & $\begin{array}{l}\text { Systemic } \\
\text { disease }\end{array}$ & $\begin{array}{l}\text { Kind of } \\
\text { cranioplast }\end{array}$ & $\begin{array}{c}\text { No. of } \\
\text { resorbable } \\
\text { 4-hole } \\
\text { plates/pins }\end{array}$ \\
\hline 1 & Trigonocephaly & Male & 6 & None & $\begin{array}{l}\text { Partial (including } \\
\text { frontoorbital } \\
\text { advancment) }\end{array}$ & $11 / 43$ \\
\hline 2 & Scaphocephaly & Male & 8 & None & Total & Total \\
\hline 3 & Scaphocephaly & Female & 10 & Hypophosphatasia & Total & $19 / 71$ \\
\hline 4 & Scaphocephaly & Male & 7 & None & Total & $21 / 72$ \\
\hline 5 & Scaphocephaly & Male & 6 & None & Total & $22 / 81$ \\
\hline 6 & Oxycephaly & Male & 19 & Hypophosphatasia & $\begin{array}{l}\text { Partial (including } \\
\text { frontoorbital } \\
\text { advancement) }\end{array}$ & $12 / 48$ \\
\hline 7 & Trigonocephaly & Female & 9 & None & Total & $18 / 72$ \\
\hline 8 & Scaphocephaly & Male & 8 & None & Total & $20 / 78$ \\
\hline 9 & Scaphocephaly & Female & 7 & None & Total & $21 / 84$ \\
\hline 10 & Scaphocephaly & Male & 11 & None & & \\
\hline
\end{tabular}

kness of $1 \mathrm{~mm}$ were used according to the manufacturer's instructions for the remodeling and fixation of the cranial vault. They were trimmed to the appropriate contour with a heating pen. Subsequently, holes with a diameter of 1.6 $\mathrm{mm}$ were drilled conventionally. The plates were fixed to the bone by $2.1 \times 4 \mathrm{~mm}$ pins (SonicWeld/Resorb-X, KLS Martin, Tuttlingen, Germany), which were inserted and welded to the bone and fused to the osteosynthesis plates by ultrasound assistance. The number of plates and pins used for each patient were documented. The authors did not use resorbable meshes. Wound closure was carried out with resorbable sutures. Postoperatively, all patients were monitored on a pediatric intensive care unit for 24 hours.

The course of wound healing after surgery was documented. Clinical follow-up evaluations were carried out 1 , 3, 6, 9, 12 and 18 months after surgery. The patients were examined for signs of local infection at the incision site, stability of the remodeled cranial vault and the palpability of the osteosynthesis material. If secondary surgery was necessary, the reason for and the kind of intervention and the postoperative course of wound healing were documented. During the intervention tissue specimens were harvested for pathological histological examination and a smear of the wound was taken.

If a computed tomography scan had to be acquired during the postoperative course, it was checked for remnants of the resorbable material.

\section{Results}

The osteosynthesis material could be used successfully according to the manufacturer's protocol. Intraoperatively, no complications occurred. The number of plates and pins used for each patient is given in Table 1. Wound healing proceeded uneventfully during the inpatient period of 10 days. During the follow-up examinations all remodeled cranial vaults were stable on palpation. In each patient at least one osteosynthesis plate was palpable at the end of the follow-up period. Three patients did not exhibit any sign of inflammation of infection in the area of previous surgery during the complete follow-up period.

In three patients a localized bluish swelling occurred in scar tissue of the former incision site (Figure 1a). In a female patient with hypophosphatasia this finding became visible three months after surgery. In the remaining two patients without systemic disease a similar finding appeared after 9 and 12 months after surgery, respectively. In these three patients there was no history of trauma or other events before the lesions developed.

In the three patients secondary surgery was carried out 


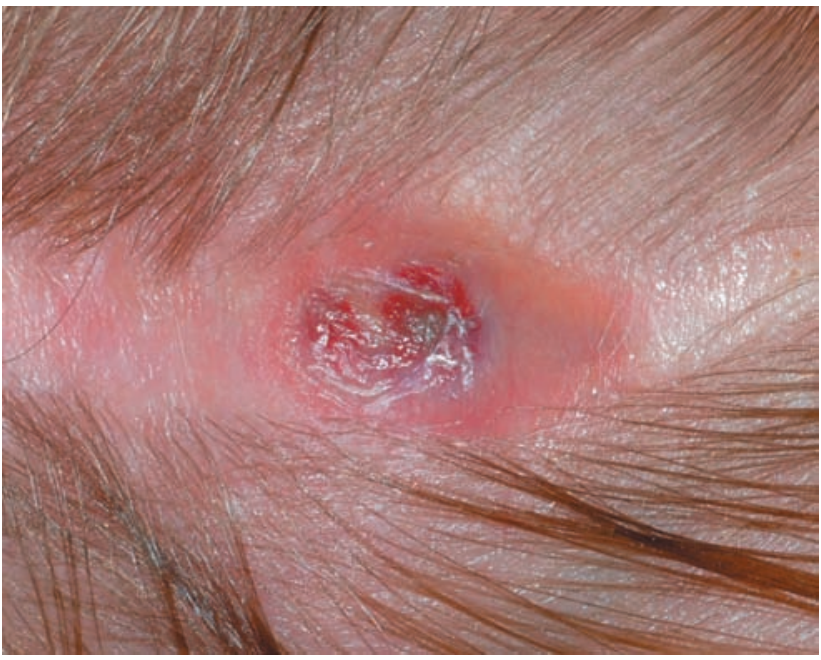

Figure 1a. Tissue bulge with chronically inflamed scar formation covering the resorbable plates in the region of surgical incision.

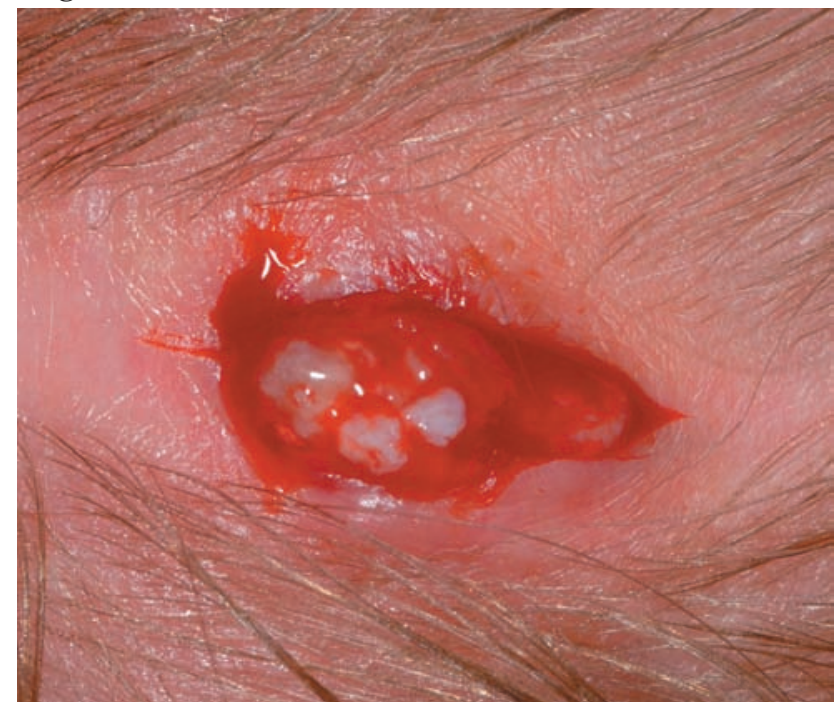

Figure 1b. Surgical site during revision surgery: scar tissue and chronically inflamed tissue surrounding the resorbable osteosynthesis material.

under general anesthesia on an outpatient basis. An incision was made in the region of the swelling (Figure $1 \mathrm{~b} \& 1 \mathrm{c}$ ). A smear of the wound was carried out and biopsies were harvested (Figure $2 \& 3$ ).

In the microbiological examination Staphylococcus aureus could be identified in the patient suffering from hypophosphatasia. There were no resistant strains. The bacteria were sensitive to penicillin that was administered for five days. Light microscopic examination of the tissue sample of the patient suffering from hypophosphatasia revealed multiple strips of fibrovascular tissue enveloping an exuberant foreign-body giant cell reaction with areas of necrotic material and chronic inflammation. In addition

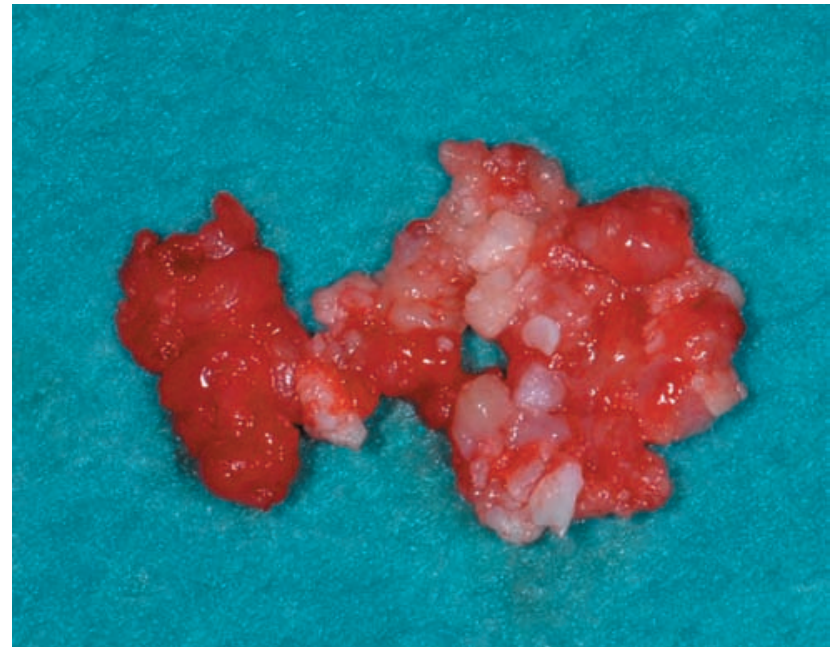

Figure 1c. Removed resorbable material with adjacent chronically inflamed fibrotic tissue bulge; size of the removed material: $2 \times 1 \mathrm{~cm}$.

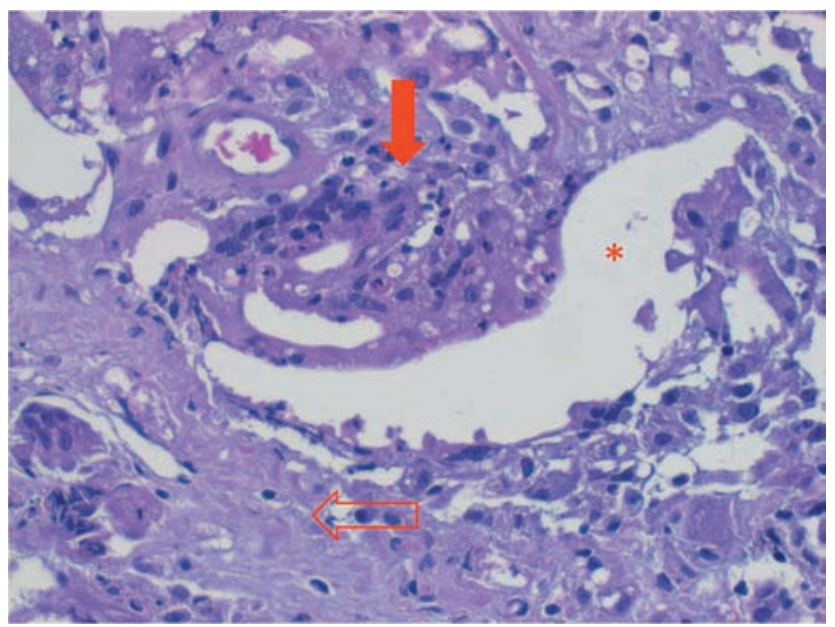

Figure 2. Histological specimen of a tissue sample harvested during secondary surgery due to chronic inflammation 9 months after ultrasound activated resorbable pin osteosynthesis during craniosynostosis surgery: fibrovascular tissue $(\boxminus)$ and foreign body cell reaction $(\rightarrow$ ) enveloping the resorbable material (*); staining: H.E., magnification: $400 x$.

small spots of purulent infection could be identified. In the tissue samples of the remaining two patients also a foreign body giant cell reaction was found (Figure 4). However, there was no purulent infection. During the postoperative course wound healing proceeded uneventfully in the three patients.

In the female patient who suffered from hypophosphatasia a computed tomography scan was carried out six months after surgery in order to control bony healing. The radiological examination revealed that osteosynthesis 


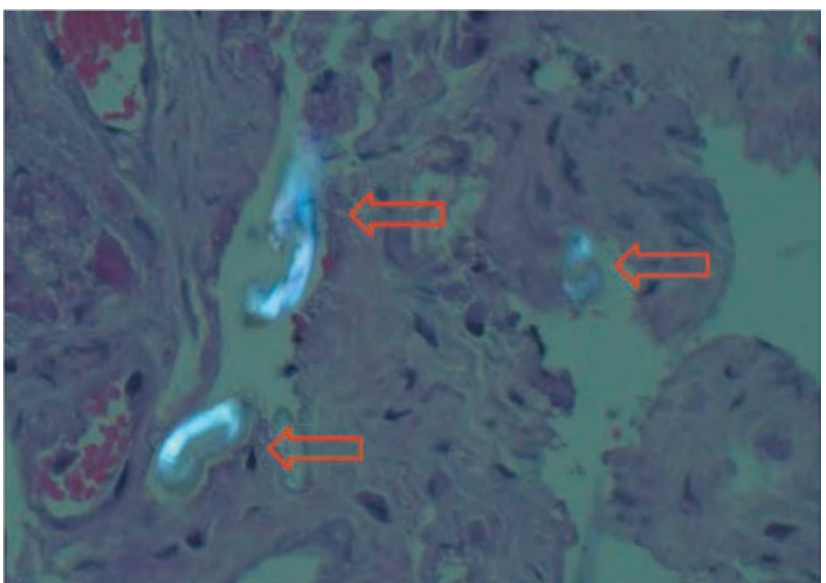

Figure 3. Spotting parts of the crystalline resorbable material $(\Longrightarrow)$ surrounded by fibrovascular tissue, polarization microscopy; staining: H.E., magnification: 400x.

plates could be still delineated at that time. Bony defects of the calvarium were still visible.

\section{Discussion}

In the past only a limited number of studies has been dedicated to ultrasound activated resorbable pin osteosynthesis. Two in vitro studies and four experimental animal trials have been carried out that demonstrated the excellent

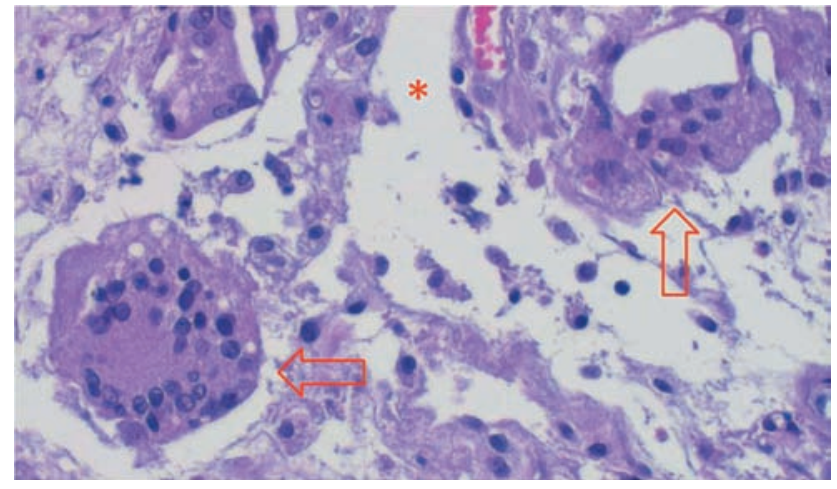

Figure 4. Giant cells with necrotic intracellular debris $(\Rightarrow)$ next to a fraction of the resorbable material (*); staining: H.E., magnification: $400 x$.

stability and handling characteristics of the osteosynthesis system (Table $2^{6,16,17,21,22,26}$ ). The clinical studies that were performed on pediatric craniosynostosis patients also showed favourable outcomes with low complication rates (Table $3^{4,5,7,24}$ ). However, it has to be kept in mind that all of these studies were retrospective.

The lack of prospective studies seems to be the reason for the fact that the complication rate in resorbable osteosynthesis is still a matter of debate. In craniofacial surgery a percentage of complications below $1 \%$ has been described as well as complication rates of up to $15.4 \% 0^{9,13,25}$.

Table 2

Experimental studies on ultrasound activated resorbable pin osteosynthesis

\begin{tabular}{|c|c|c|c|c|c|}
\hline Authors & $\begin{array}{l}\text { Study } \\
\text { design }\end{array}$ & $\begin{array}{l}\text { Kind of ani- } \\
\mathrm{mal} / \mathrm{material}\end{array}$ & $\begin{array}{l}\text { Number of ani- } \\
\text { mals/experiments }\end{array}$ & $\begin{array}{l}\text { Follow-up } \\
\text { interval (days) }\end{array}$ & Results \\
\hline $\begin{array}{l}\text { Pilling et al. } \\
2007(\mathrm{a})^{21}\end{array}$ & In vivo & Sheep & 11 & $7-63$ & - No foreign body reaction \\
\hline $\begin{array}{l}\text { Pilling et al. } \\
2007(\mathrm{~b})^{22}\end{array}$ & In vivo & Sheep & 13 & $7-196$ & $\begin{array}{l}\text { - Reduced insertion time } \\
\text { - Higher load capacity } \\
\text { compared to screwed fixed } \\
\text { resorbable materials }\end{array}$ \\
\hline $\begin{array}{l}\text { Mai et al. } \\
2007^{16}\end{array}$ & In vivo & Sheep & 12 & $14 \& 63-\mathrm{Nc}$ & $\begin{array}{l}\text { - No early or late infection } \\
\text { eign body reaction }\end{array}$ \\
\hline $\begin{array}{l}\text { Meissner et } \\
\text { al. } 2008^{17}\end{array}$ & In vivo & Sheep & 16 & $1-196$ & $\begin{array}{l}\text { - Higher load capacity } \\
\text { compared to screwed fixed } \\
\text { resorbable materials }\end{array}$ \\
\hline $\begin{array}{l}\text { Schneider et } \\
\text { al. } 2009^{26}\end{array}$ & In vitro & $\begin{array}{l}\text { Synthetic } \\
\text { blocks }\end{array}$ & 6 & - & $\begin{array}{l}\text { - Equal load capacity } \\
\text { compared to screwed fixed } \\
\text { resorbable materials }\end{array}$ \\
\hline $\begin{array}{l}\text { Buijs et al. } \\
2007^{6}\end{array}$ & In vitro & $\begin{array}{l}\text { Synthetic } \\
\text { blocks }\end{array}$ & 9 & - & $\begin{array}{l}\text { - Equal load capacity } \\
\text { compared to screwed fixed } \\
\text { resorbable materials }\end{array}$ \\
\hline
\end{tabular}


Table 3

Clinical studies on ultrasound activated resorbable pin osteosynthesis

\begin{tabular}{|l|c|c|c|c|}
\hline Authors & $\begin{array}{l}\text { Number of } \\
\text { patients } n\end{array}$ & $\begin{array}{c}\text { Average age at the time } \\
\text { of cranioplasty (month) } \\
\text { mean (min/max) }\end{array}$ & $\begin{array}{c}\text { Follow-up interval } \\
\text { (month) } \\
\text { mean (min/max) }\end{array}$ & $\begin{array}{c}\text { Complications } \\
\text { n (specification) }\end{array}$ \\
\hline $\begin{array}{l}\text { Aldana et } \\
\text { al. 20094 }\end{array}$ & 12 & $66(2 / 216)$ & $11.5(1 / 22)$ & $\begin{array}{l}\text { 1 early infection (caused by } \\
\text { femoral catheter with the need } \\
\text { of plate removal) } \\
\text { 2 cases of swelling due to infec- } \\
\text { tion on the skull overlying the } \\
\text { implant plates 9-10 month post- } \\
\text { operatively (spontaneous resolve } \\
\text { after 4 weeks) }\end{array}$ \\
\hline $\begin{array}{l}\text { Eckelt et } \\
\text { al. 20077 }\end{array}$ & 8 & $21(12 / 48)$ & $12(12 / 12)$ & $\begin{array}{l}\text { 1 refixation (titanium plate) } \\
\text {, }\end{array}$ \\
\hline $\begin{array}{l}\text { Arnaud \& } \\
\text { Renier } \\
\text { 20095 }\end{array}$ & 20 & $15(3 / 30)$ & 30 & $\begin{array}{l}\text { Resorption bulge around the } \\
\text { materials 6-12 month post } \\
\text { operation in all cases } \\
\text { fracture of a resorbable plate }\end{array}$ \\
\hline $\begin{array}{l}\text { Reichwein } \\
\text { et al. 200924 }\end{array}$ & n.s. & n.s. & n.s. & n.s. \\
\hline
\end{tabular}

n.s. $=$ not specified

Delayed foreign body reactions have been reported to present up to 2 years after implantation. Therefore, a major criticism with previous studies was that the follow-up of children who were operated on because of craniosynostoses and received ultrasound activated resorbable pin osteosynthesis, was limited to an average period of 12 months $^{4,7,24}$. Recently, a study performing a follow-up of 30 months after craniosynostosis surgery with ultrasound activated resorbable pin osteosynthesis described complications only within the first postoperative year that were comparable to studies using shorter follow up periods ${ }^{5}$. Surprisingly, in the present study foreign body reactions were encountered in 3 out of 10 patients in the first year after surgery, respectively. The foreign body reactions were located under the scars in the region of the former incision sites of the scalp. It seems that the scar of the incision site is a locus minoris resistentiae. Infections of that site following craniosynostosis surgery have been described previously ${ }^{3}$. Moreover, it has been shown that during the degradation process, the thickness of the plates increases by up to $300 \%{ }^{11}$. This aspect may be an additional factor that paves the way for complications. In 8 of the 10 patients of the present study the cranial vault had to be remodeled completely. It is impossible to precisely predict where the incision site will lie after completion of the procedure. Therefore, sometimes it is inevitable that osteosynthesis plates interfere with the incision site. Although infections at the incision site are a well known problem in craniofacial surgery, they have never been attributed to the interference with resorbable plates $^{3}$. However, with the use of ultrasound activated resorbable pin osteosynthesis it seems that the placement of plates near the incision site should be avoided wherever possible.

So far, foreign body reactions have not been described in the literature for resorbable osteosynthesis material composed of poly D- and L-polylactate isomers which was used in this study ${ }^{4}$. This aspect may be the result of the fact that all clinical studies that were carried out on children undergoing craniosynostosis surgery by the use of resorbable ultrasound activated resorbable pin osteosynthesis were not focused on assessing complications $s^{4,7,24}$.

Up to now, it has not been well investigated in how far the material properties of the thermoplastic amorphous polylactide material changes by the ultrasound activation. However, it has been shown experimentally that plastic deformation of polylactide leads to structure alterations and substantial molecular rearrangement with a relevant change in material properties ${ }^{23}$. So far, it has been said that polylactide does not generate crystalline debris during degradation ${ }^{14}$. Clinically, crystalline debris could not be found in histological samples in previous studies ${ }^{15}$. However, the histological samples of the present study showed that there were crystalline remnants of the material (Fig. 3 ). These findings may reveal that ultrasound activation of polylactide alters the material properties in a way that the degradation process is changed. As a consequence, the 
change in material properties may be a major factor for the high complication rat in the present study.

Generally, complications encountered with ultrasound activated resorbable pin osteosynthesis do not seem to differ from that of conventional resorbable osteosynthe$\operatorname{sis}^{27}$. The three patients who required reoperation for the removal of the remnants of the resorbable plates, were treated on an outpatient basis. Surgery only took a few minutes and postoperative healing was uneventful. In none of the patients a recurrence of the problem could be found during the follow-up period. However, reoperation is one of the major issues that surgeons try to avoid in craniofacial surgery and that prompts them to use resorbable osteosynthesis. An alternative to surgery would have been waiting for spontaneous perforation of the lesion and discharge of the material with subsequent spontaneous healing of the lesion. However, this way of dealing with the problem seems inappropriate because it may increase the risk of infection including the intracranial region. As a consequence, the removal of the remnants of the resorbable plates had been preferred. Therefore, although the number of patients followed up in the present study is low, it seems that the use of ultrasound activated resorbable pin osteosynthesis has to be reviewed critically as far as the avoidance of reoperation is concerned. Actually, in the present study it was decided to stop using the material because of the high complication rate. For the team, the need for reoperation with the new anesthetic risk definitely did outweigh the advantages of the ultrasound activated resorbable pin osteosynthesis. Although the use of resorbable pins is time-saving and technically less demanding than the use of resorbable screws ${ }^{7,22}$, the team decided to restart using conventional resorbable screws, before a complication rate has been confirmed that is as low as that of conventional resorbable osteosynthesis material $^{18}$. The complication rate of the latter material did not exceed $5 \%$.

In the two patients who underwent cranial vault remodeling for trigonocephaly less plates were used compared to scaphocephaly and oxycephaly cases because only the frontal aspect of the cranial vault was remodeled. In the eight scaphocephaly and oxycephaly cases the number of plates was comparable. In these patients, the cranial vault was remodeled completely. So far, it is not clear from the current literature, if there is an upper limit for the number of plates applied in cranial vault reconstruction that may increase the percentage of complications. Although the complications encountered in the present study have been described previously for other resorbable materials, it seems that ultrasound activation may predispose patients for the specific problems described in the present study.

Although previous studies have shown that the use of ultrasound activated resorbable pin osteosynthesis helps to reduce operative time, this material does not seem to contribute to a reduction of the complication rate in craniosynostosis surgery $^{22}$. As the use of the resorbable pin osteosynthesis is simple and straightforward and had been practiced already for a period of two years, the complication rate does not seem to be related to a learning curve ${ }^{7}$.

It seems that advantages and possible complications of the use of the ultrasound activated resorbable pin osteosynthesis have to be weighed against each other carefully. Parents of children undergoing craniosynostosis surgery have to be informed in detail on the different aspects.

For the time being, it cannot be excluded that the use of ultrasound activated resorbable pins is the trigger for delayed foreign body reaction. Since foreign body reactions were present in a patient with hypophosphatasia as well as in 2 patients without systemic disease, it is not possible to judge to which extent hypophosphatasia contributes to the occurrence of a foreign body reaction. Independent from the underlying diseases, foreign body reactions were always found to occur next to the scar tissue of the surgical approach to the cranial vault. Hence, the parents have to be aware of the fact that especially in total cranioplasty it is not always possible to avoid positioning resorbable osteosynthesis plates in close vicinity to the former incision site of the scalp.

In all patients the resorbable osteosynthesis material remained palpable up to the final follow-up examination 18 months after surgery. Previous reports do not provide consistent results on this aspect. The palpability of the resorbable osteosynthesis material was no longer present after 4 months $^{1}$ and 6-12 month, respectively ${ }^{12}$. Whereas another study found material to be palpable up to 18 month after the operation ${ }^{5}$. Hence, long-term follow-up studies are necessary to determine time and clinical conditions of degradation of ultrasound activated resorbable osteosynthesis material.

The results of the present prospective clinical study should prompt to initiate further research on the aspect of material properties alteration of resorbable osteosynthesis material due to ultrasound activation.

All in all, it seems that this high complication rate found in the present prospective study may outweigh the advantages of ultrasound activated resorbable pin osteosynthesis. The clinical use of ultrasound activated resorbable pin osteosynthesis should be considered critically until prospective data on a larger patient population show a more favourable outcome.

\section{Conclusion}

Delayed foreign body reactions were encountered with ultrasound activated resorbable pin osteosynthesis. These foreign body reactions occurred in scar tissue in the region 
of the former incision site. Secondary surgery was necessary in three patients in order to remove the chronically inflamed tissue. Parents of children undergoing craniosynostosis surgery have to be informed on the possible risks associated with the use of this osteosynthesis material.

As a consequence of the high complication rate found in the present prospective study the use of ultrasound activated resorbable pin osteosynthesis cannot be recommended as long as larger prospective clinical studies show a more favourable outcome.

\section{References}

1. Acosta, H.L., Stelnicki, E.J., Rodriguez, L., Slingbaum, L.A.: Use of absorbable poly $(d, 1)$ lactic acid plates in cranialvault remodeling: presentation of the first case and lessons learned about its use. Cleft Palate Craniofac J 2005; 42: 333339.

2. Agarwal, S., Gupta, A., Grevious, M., Reid, R.R.: Use of resorbable implants for mandibular fixation: a systematic review. J Craniofac Surg 2009; 20: 331-339.

3. Ahmad, N., Lyles, J., Panchal, J., Deschamps-Braly. J.: Outcomes and complications based on experience with resorbable plates in pediatric craniosynostosis patients. J Craniofac Surg 2008; 19: 855-860.

4. Aldana, P.R., Roy, S., Postlethwait, R.A., James, H.E.: Ultrasound-aided fixation of a biodegradable cranial fixation system: uses in pediatric neurosurgery. J Neurosurg Pediatr 2009; 3: 420-424.

5. Arnaud, E., Renier, D.: Pediatric craniofacial osteosynthesis and distraction using an ultrasonic-assisted pinned resorbable system: a prospective report with a minimum 30 months' follow-up. J Craniofac Surg 2009; 20: 2081-2086.

6. Buijs, G.J., van der Houwen, E.B., Stegenga, B., Verkerke, G.J., Bos, R.R.: Mechanical strength and stiffness of the biodegradable SonicWeld Rx osteofixation system. J Oral Maxillofac Surg 2009; 67: 782-787.

7. Eckelt, U., Nitsche, M., Muller, A., Pilling, E., Pinzer T., Roesner, D.: Ultrasound aided pin fixation of biodegradable osteosynthetic materials in cranioplasty for infants with craniosynostosis. J Craniomaxillofac Surg 2007; 35: 218-221.

8. Eckelt, U., Pilling, E., Stelnicki, E.: A new resorbable fixation technique in craniofacial surgery. International Journal of Oral and Maxillofacial Surgery 2005; 34: 84.

9. Eppley, B.L., Morales, L., Wood, R., Pensler, J., Goldstein, J., Havlik, R.J., Habal, M., Losken, A., Williams, J.K., Burstein, F., Rozzelle, A.A., Sadove, A.M.: Resorbable PLLA-PGA plate and screw fixation in pediatric craniofacial surgery: clinical experience in 1883 patients. Plast Reconstr Surg 2004; 114: 850-856.

10. Habal, M.B., Pietrzak, W.S.: Key points in the fixation of the craniofacial skeleton with absorbable biomaterial. J Craniofac Surg 1999; 10: 491-499.
11. Heidemann, W., Gerlach, K.L.: Imaging of biodegradable osteosynthesis materials by ultrasound. Dentomaxillofac Radiol 2002; 31: 155-558.

12. Imola, M.J., Hamlar, D.D., Shao, W., Chowdhury, K., Tatum, S.: Resorbable plate fixation in pediatric craniofacial surgery: long-term outcome. Arch Facial Plast Surg 2001; 3: 79-90.

13. Kumar, C.R., Sood, S., Ham, S.: Complications of bioresorbable fixation systems in pediatric neurosurgery. Childs Nerv Syst 2005; 21: 205-210.

14. Leiggener, C.S., Curtis, R., Müller, A.A., Pfluger, D., Gogolewski, S., Rahn, B.A.: Influence of copolymer composition of polylactide implants on cranial bone regeneration. Biomaterials 2006; 27: 202-207.

15. Mackool, R., Yim, J., McCarthy, J.G.: Delayed degradation in a resorbable plating system. J Craniofac Surg 2006; 17: 194-197.

16. Mai, R., Lauer, G., Pilling, E., Jung, R., Leonhardt, H., Proff, P., Stadlinger, B., Pradel, W., Eckelt, U., Fanghänel, J., Gedrange, T.: Bone welding--a histological evaluation in the jaw. Ann Anat 2007; 189: 350-355.

17. Meissner, H., Pilling, E., Richter, G., Koch, R., Eckelt, U., Reitemeier, B.: Experimental investigations for mechanical joint strength following ultrasonically welded pin osteosynthesis. J Mater Sci Mater Med 2008; 19: 2255-2259.

18. Munoz-Casado, M.J., Romance, A.I., Garcia-Recuero, J.I.: Bioabsorbable osteofixation devices in craniosynostosis. Clinical experience in 216 cases. Neurocirugia 2009; 20: 255261.

19. Pensler, J.M.: Role of resorbable plates and screws in craniofacial surgery. J Craniofac Surg 1997; 8: 129-134.

20. Pietrzak, W.S., Sarver, D.R., Verstynen, M.L.: Bioabsorbable polymer science for the practicing surgeon. J Craniofac Surg 1997; 8: 87-91.

21. Pilling, E., Mai, R., Theissig, F., Stadlinger, B., Loukota, R., Eckelt, U.: An experimental in vivo analysis of the resorption to ultrasound activated pins (Sonic weld) and standard biodegradable screws (ResorbX) in sheep. Br J Oral Maxillofac Surg 2007; 45: 447-450.

22. Pilling, E., Meissner, H., Jung, R., Koch, R., Loukota, R., Mai, R., Reitemeier, B., Richter, G., Stadlinger, B., Stelnicki, E., Eckelt, U.: An experimental study of the biomechanical stability of ultrasound-activated pinned (SonicWeld $\mathrm{Rx}+\mathrm{Resorb}-\mathrm{X}$ ) and screwed fixed (Resorb-X) resorbable materials for osteosynthesis in the treatment of simulated craniosynostosis in sheep. Br J Oral Maxillofac Surg 2007; 45: 451-456.

23. Pluta, M., Galeski, A.: Plastic deformation of amorphous poly(L/DL-lactide): structure evolution and physical properties. Biomacromolecules 2007; 8: 1836-1843.

24. Reichwein, A., Schicho, K., Moser, D., Seemann, R., Poeschl, P., Baumann, A., Ewers, R.: Clinical experiences with resorbable ultrasonic-guided, angle-stable osteosynthesis 
Nkenke et al

in the panfacial region. J Oral Maxillofac Surg 2009; 67: 12111217.

25. Sanger, C., Soto, A., Mussa, F., Sanzo, M., Sardo, L., Donati, P.A., Di Pietro, G., Spacca, B., Giordano, F., Genitori, L.: Maximizing results in craniofacial surgery with bioresorbable fixation devices. J Craniofac Surg 2007; 18: 926-930.

26. Schneider, M., Loukota, R., Reitemeier, B., Meissner, H., Stadlinger, B., Eckelt, U., Richter, G.: Bone block fixation by ultrasound activated resorbable pin osteosynthesis: a biomechanical in vitro analysis of stability. Oral Surg Oral Med Oral Pathol Oral Radiol Endod 2009; 109: 79-85.

27. Tharanon, W., Sinn, D.P., Hobar, P.C., Sklar, F.H., Salomon, J.: Surgical outcomes using bioabsorbable plating systems in pediatric craniofacial surgery. J Craniofac Surg 1998; 9: 441-447.
Neurocirugía 2011; 22: 498-506

28. Yerit, K.C., Enislidis, G., Schopper, C., Turhani, D., Wanschitz, F., Wagner, A., Watzinger, F., Ewers, R.: Fixation of mandibular fractures with biodegradable plates and screws. Oral Surg Oral Med Oral Pathol Oral Radiol Endod 2002; 94: 294-300.

Nkenke, E.; Vairaktaris, E.; Schwarz, S.; Eyüpoglu, I.; Ganslandt, O.; Leis, T.; Knipfer, C.; Stelzle, F.: Prospective assessment of complications associated with ultrasound activated resorbable pin osteosynthesis in pediatric craniofacial surgery: preliminary results. Neurocirugía 2011; 22: 495-506.

Corresponding author: Prof. Dr. Emeka Nkenke. Department of Oral and Maxillofacial Surgery. Glücksstrasse 11.

91054 Erlangen, Germany

e-mail: emeka.nkenke@uk-erlangen.de 